\title{
EVALUASI PROGRAM PENGENTASAN KEMISKINAN DITINJAU DARI PROSES PEMBERDAYAAN EKONOMI PADA KEGIATAN PNPM MANDIRI PERDESAAN TELUK BELITUNG KABUPATEN KEPULAUAN MERANTI
}

\author{
Mahendra Romus \\ Nurlasera \\ Dosen Fakultas Ekonomi dan Ilmu Sosial \\ Universitas Islam Negeri Sultan Syarif Kasim Riau
}

\begin{abstract}
Abstrak
Penelitian ini bertujuan untuk mengevaluasi program pengentasan kemiskinan pada kegiatan PNPM Mandiri Perdesaan di desa Teluk Belitung Kabupaten Kepulauan Meranti pada tahun 2013. Analisis data menggunakan analisis deskriptif. Hasil penelitian menunjukkan bahwa program PNPM Mandiri Perdesaan di desa Teluk Belitung Kecamatan Merbau Kabupaten Kepulauan Meranti telah berjalan dengan baik dan masyarakat merasakan manfaat dari program tersebut dalam proses pemberdayaan ekonomi untuk mengentaskan kemiskinan di desa tersebut. Hal ini dilihat dari meningkatnya masyarakat yang berpartisipasi dalam mengakses dana bergulir PNPM Mandiri Perdesaan, meningkatnya kapasitas kelembagaan desa, meningkatnya usaha produktif masyarakat setempat.
\end{abstract}

Kata Kunci : Kemiskinan, Pemberdayaan Ekonomi, PNPM

\section{PENDAHULUAN}

Permasalahan kemiskinan yang cukup kompleks membutuhkan intervensi semua pihak secara bersama dan terkoordinasi. Namun penanganannya selama ini cenderung parsial dan tidak berkelanjutan. Peran dunia usaha dan masyarakat pada umumnya juga belum optimal. Kerelawanan sosial dalam kehidupan masyarakat yang dapat menjadi sumber penting pemberdayaan dan pemecahan akar permasalahan kemiskinan juga mulai luntur. Untuk itu diperlukan perubahan yang bersifat sistemik dan menyeluruh dalam upaya penanggulangan kemiskinan.

Untuk meningkatkan efektivitas penanggulangan kemiskinan dan penciptaan lapangan kerja, pemerintah meluncurkan Program Nasional Pemberdayaan Masyarakat (PNPM) Mandiri mulai tahun
2007. Melalui PNPM Mandiri dirumuskan kembali mekanisme upaya penanggulangan kemiskinan yang melibatkan unsur masyarakat, mulai dari tahap perencanaan, pelaksanaan, hingga pemantauan dan evaluasi. Melalui proses pembangunan partisipatif, kesadaran kritis dan kemandirian masyarakat, terutama masyarakat miskin, dapat ditumbuhkembangkan sehingga mereka bukan sebagai obyek melainkan subyek upaya penanggulangan kemiskinan.

Pelaksanaan PNPM Mandiri tahun 2007 dimulai dengan Program Pengembangan Kecamatan (PPK) sebagai dasar pengembangan pemberdayaan masyarakat di perdesaan beserta program pendukungnya seperti PNPM Generasi; Program Penanggulangan Kemiskinan di Perkotaan (P2KP) sebagai dasar bagi pengembangan pemberdayaan masyarakat di perkotaan; dan Percepatan Pembangunan Daerah Tertinggal 
dan Khusus (P2DTK) untuk pengembangan daerah tertinggal, pasca bencana, dan konflik. Mulai tahun 2008 PNPM Mandiri diperluas dengan melibatkan Program Pengembangan Infrastruktur Sosial Ekonomi Wilayah (PISEW) untuk mengintegrasikan pusat-pusat pertumbuhan ekonomi dengan daerah sekitarnya. PNPM Mandiri diperkuat dengan berbagai program pemberdayaan masyarakat yang dilaksanakan oleh berbagai departemen/sektor dan pemerintah daerah. Pelaksanaan PNPM Mandiri 2008 juga akan diprioritaskan pada desa-desa tertinggal.

Dengan pengintegrasian berbagai program pemberdayaan masyarakat ke dalam kerangka kebijakan PNPM Mandiri, cakupan pembangunan diharapkan dapat diperluas hingga ke daerah-daerah terpencil dan terisolir. Efektivitas dan efisiensi dari kegiatan yang selama ini sering berduplikasi antar proyek diharapkan juga dapat diwujudkan. Mengingat proses pemberdayaan pada umumnya membutuhkan waktu 5-6 tahun, maka PNPM Mandiri akan dilaksanakan sekurangkurangnya hingga tahun 2015. Hal ini sejalan dengan target waktu pencapaian tujuan pembangunan milenium atau Millennium Development Goals (MDGs)*. Pelaksanaan PNPM Mandiri yang berdasar pada indikator-indikator keberhasilan yang terukur akan membantu Indonesia mewujudkan pencapaian target-target MDGs tersebut (MDGs adalah kesepakatan global untuk mencapai target pembangunan bersama yaitu memberantas kemiskinan dan kelaparan; pendidikan dasar untuk semua; kesetaraan jender dan pemberdayaan perempuan; mengurangi angka kematian anak; meningkatkan kesehatan ibu; memerangi penyakit menular dan penyakit lainnya; menjamin kelestarian lingkungan hidup; dan mengembangkan kemitraan global untuk pembangunan).
Kabupaten Kepulauan Meranti adalah salah satu kabupaten di Provinsi Riau, ibu kotanya adalah Selat Panjang. Kabupaten Kepulauan Meranti terdiri dari Pulau Tebingtinggi, Pulau Padang, Pulau Merbau, Pulau Ransang, Pulau Topang, Pulau Manggung, Pulau Panjang, Pulau Jadi.

Tuntutan pemekaran Kabupaten Kepulauan Meranti sudah diperjuangkan oleh masyarakat sejak tahun 1957. Seruan pemekaran kembali diembuskan tahun 1970 dan 1990-an hingga tahun 2008. Yang merupakan satu-satunya kawedanan di Riau yang belum dimekarkan saat itu. Pada tanggal 19 Desember 2008, DPR RI mengesahkan pembentukan Kabupaten Kepulauan Meranti di Riau yang terpisah dari Kabupaten Bengkalis.

Kabupaten Kepulauan Meranti merupakan daerah termiskin di provinsi Riau (cekau.com, 20 april 2012). Rendahnya pendapatan perkapita penduduk Kep. Meranti dari 238 ribu warga, 42\% diantaranya tergolong miskin. Infrastruktur dasar seperti jalan, jembatan dan fasilitas umum lainnya masih minim. Secara geografis terdiri dari pulau-pulau, sisanya laut dan selat. Akses banyak menggunakan transportasi laut. Pertumbuhan ekonomi kab Meranti tumbuh rata-rata 7,24\% per tahun (Rayan Pribadi, 10 April 2012).

PNPM Mandiri Perdesaan PNPM Mandiri Perdesaan adalah program untuk mempercepat penanggulangan kemiskinan secara terpadu dan berkelanjutan. Pendekatan PNPM Mandiri Perdesaan merupakan pengembangan dari Program Pengembangan Kecamatan (PPK), yang selama ini dinilai berhasil. Beberapa keberhasilan PPK adalah berupa penyediaan lapangan kerja dan pendapatan bagi kelompok rakyat miskin, efisiensi dan efektivitas kegiatan, serta berhasil menumbuhkan kebersamaan dan partisipasi masyarakat. 
Salah satu desa di kecamatan Merbau kab. Kepulauan Meranti adalah desa Teluk Belitung yang mempunyai kelompok paling banyak yang dilayani pada tahun 2013 melalui Program PNPM Mandiri Perdesaan. Program ini telah dilaksanakan di desa Teluk Belitung sejak tahun 2007.

\section{a. Perumusan Masalah}

Berdasarkan uraian sebelumnya maka rumusan masalah pada penelitian ini adalah: bagaimanakah program pengentasan kemiskinan ditinjau dari proses pemberdayaan ekonomi pada kegiatan PNPM Mandiri Perdesaan di desa Teluk Belitung Kab. Kepulauan Meranti.

\section{b. Tujuan Penelitian}

Berdasarkan rumusan masalah yang dikemukakan di atas maka tujuan penelitian adalah : untuk mengetahui bagaimanakah program pengentasan kemiskinan ditinjau dari proses pemberdayaan ekonomi pada kegiatan PNPM Mandiri Perdesaan di desa Teluk Belitung Kab. Kepulauan Meranti.

\section{Telaah Pustaka \\ 1. Kemiskinan}

Kemiskinan merupakan konsep dan fenomena yang berwayuh wajah atau berbagai bentuk dan bermatra multidimensial atau dengan arti ayang luas. SMERU dalam Soeharto (2005) menunjukan bahwa kemiskinan memilki beberapa ciri: 1. Ketidakmampuan memenuhi kebutuhan konsumsi dasar (pangan, sandang, dan papan). 2. Ketiadaan akses terhadap kehidupan hidup dasar lainnya (kesehatan, pendidikan, sanitasi, air bersih dan transportasi). 3. Ketiadaan jaminan masa depan (karena tiada investasi untuk pendidikan dan keluarga). 4. Kerentanan terhadap goncangan yang bersifat individuala maupun massal. 5 . Rendahnya kualitas sumbr daya manusia dan keterbatasan sumber alam. 6.
Ketidakterlibatan dalam kegiatan sosial masyarakat.

\section{Pemberdayaan}

Pemberdayaan menurut Parson dalam Soeharto (2005) adalah sebuah proses dimana orang menjadi cukup kuat untuk berpartisipasi dalam berbagai pengontrolan atas dan mempengaruhi terhadap kejadian kejadian serta lembaga - lembaga yang mana mempengaruhi kehidupannya, pemeberdayaan menekankan orang memperoleh keterampilan, pengetahuan dan kekuasaan yang cukup untuk mempengaruhi kehidupannya dan kehidupan orang lain yang menjadi perhatiannya. Sutrisno dalam http://teoripemberdayaan.blogspot.com

(2012) menjelaskan, dalam perspektif pemberdayaan, masyarakat diberi wewenang untuk mengelola sendiri dana pembangunan baik yang berasal dari pemerintah maupun dari pihak lain, disamping mereka harus aktif berpartisipasi dalam proses pemilihan, perencanaan, dan pelaksanaan pembangunan. Ada beberapa rumusan konsep pemberdayaan para ahli yang intinya dapat dinyatakan bahwa pemberdayaan adalah sebagai upaya berencana yang dirancang untuk membuat komunitas atau masyarakat berubah dari keadaan ketidakberdayaan menjadi berdaya dengan kemampuan yang didapat dari proses meningkatkan keterampilan untuk menguasai potensi yang terdapat dalam diri masyarakat, dilakukan secara teroganisir dan berlanjut sehingga masyarakat dapat menentukan arah masa depannya, sementara itu pemerintah disisi lain menempatkan diri sebagai lembaga yang menunjang dan memotivasi masyarakat.

Pemberdayaan masyarakat adalah upaya untuk menciptakan/meningkatkan kapasitas masyarakat, baik secara individu maupun berkelompok, dalam memecahkan berbagai persoalan terkait upaya peningkatan kualitas hidup, kemandirian, dan kesejahteraannya. 
Pemberdayaan masyarakat memerlukan keterlibatan yang lebih besar dari perangkat pemerintah daerah serta berbagai pihak untuk memberikan kesempatan dan menjamin keberlanjutan berbagai hasil yang dicapai.

\section{PNPM Mandiri}

PNPM Mandiri adalah program nasional dalam wujud kerangka kebijakan sebagai dasar dan acuan pelaksanaan program-program penanggulangan kemiskinan berbasis pemberdayaan masyarakat. PNPM Mandiri dilaksanakan melalui harmonisasi dan pengembangan sistem serta mekanisme dan prosedur program, penyediaan pendampingan, dan pendanaan stimulan untuk mendorong prakarsa dan inovasi masyarakat dalam upaya penanggulangan kemiskinan yang berkelanjutan.

\section{Evaluasi PNPM Mandiri Perdesaan}

Evaluasi Kebijakan Muhadjir dalam Joko Widodo (2009) mengatakan evaluasi kebijakan merupakan suatu proses untuk menilai seberapa jauah kebijakan dapat "membuahkan hasil", yaitu dengan membandingkan hasil dengan tujuan /target yang ditentukan. Sedangkan menurut Jones dalam Joko Widodo (2009) mengartikan evaluasi kebijakan sebagai suatu aktivitas yang dirancang untuk menilai hasil- hasil kebijakan pemerintah yang mempunyai perbedaan-perbedaan yang sangat penting dalam spesifikasi objeknya, teknik-teknik pengukurannya, dan metode analisisnya.

\section{METODE PENELITIAN}

Penelitian dilaksanakan di desa Teluk Belitung Kecamatan Merbau Kabupaten Kepulauan Meranti Provinsi Riau. Jenis dan sumber data dalam penelitian ini data yang digunakan adalah data primer dan data sekunder. Pemilihan dan pengambilan sumber data dilakukan secara sampel purposive (Purposial Sampling). Pada teknik pengambilan sampel purposive, sampel ditetapkan secara sengaja oleh peneliti. Dalam hal ini didasarkan atas kriteria / pertimbangan tertentu. (Subagiyo, 2003 : 94). Dalam penelitian ini untuk mendapatkan data penulis menggunakan key-informan. Adapun key-informan dalam penelitian ini adalah; 1. Penanggung Jawab Operasional Kegiatan (PJOK) PNPM Mandiri Perdesaan. 2. Kepala Desa Teluk Belitung sebagai Pembina dan pengendali kelancaran keberhasilan pelaksanaan PNPM 3. Tim pengelola kegiatan (TPK) yang berperan sebagai bagian dari pelaksana sekaligus pengontrol atas pelaksanaan dari kegiatan PNPM mandiri. 4. Masyarakat sebagai penerima manfaat yang dijadikan responden sebanyak 5 orang mewakili 5 kelompok. Informasi menurut J. Moleong (2009 : 900) adalah orang yang memberikan informasi tentang situasi dan kondisi latar penelitian, ia berkewajiban secara sekarela menjadi anggota tim dengan penelitian walaupun bersifat informal.

Teknik Pengumpulan Data

Teknik pengumpulan data penulis menggunakan beberapa cara, yaitu : 1 . Penelitian Kepustakaan (Library Research). 2. Penelitian Lapangan (field work research), yaitu penelitian yang dilakukan secara langsung ke lapangan dengan menggunakan cara-cara sebagai berikut: a. Observasi. b. Wawancara. c. Penelitian Dokumen . Dari data yang diperoleh di atas baik melalui observasi dan wawancara maupun dokumentasi, data tertulis serta data dari key-informan yang diolah dan dipadukan sehingga menghasilkan data yang akurat.

Teknik Analisis Data Miles dan Huberman (1992 : 19) menjelaskan bahwa analisis data kualitatif merupakan proses siklus dan interaktif yang bergerak diantaraa empat "sumbu" yaitu mengumpullkan data, reduksi, penyajian data dan kesimpulan, 
yaitu : 1. Pengumpulan data 2. Reduksi / penyederhanaan data 3. Penyajian data 4 . Penarikan kesimpulan data yang diperoleh di lapangan selanjutnya dianalisis dengan melakukan pemaparan dan interpretasi. Dalam penelitian ini penulis menggunakan analisis data deskriptif kualitatif.

\section{HASIL DAN PEMBAHASAN \\ 1. Program PNPM Mandiri Perdesaan}

Program PNPM Mandiri Perdesaan bertujuan meningkatnya kesejahteraan dan kesempatan kerja masyarakat miskin secara mandiri. Secara lebih khusus tujuan PNPM Mandiri adalah :

a. Meningkatnya partisipasi seluruh masyarakat, termasuk masyarakat miskin, kelompok perempuan, komunitas adat terpencil, dan kelompok masyarakat lainnya yang rentan dan sering terpinggirkan ke dalam proses pengambilan keputusan dan pengelolaan pembangunan.

b. Meningkatnya kapasitas kelembagaan masyarakat yang mengakar, representatif, dan akuntabel.

c. Meningkatnya kapasitas pemerintah dalam memberikan pelayanan kepada masyarakat terutama masyarakat miskin melalui kebijakan, program dan penganggaran yang berpihak pada masyarakat miskin (pro-poor).

d. Meningkatnya sinergi masyarakat, pemerintah daerah, swasta, asosiasi, perguruan tinggi, lembaga swadaya masyarakat, organisasi masyarakat, dan kelompok peduli lainnya, untuk mengefektifkan upaya-upaya penanggulangan kemiskinan.

e. Meningkatnya keberdayaan dan kemandirian masyarakat, serta kapasitas pemerintah daerah dan kelompok peduli setempat dalam menanggulangi kemiskinan di wilayahnya.

f. Meningkatnya modal sosial masyarakat yang berkembang sesuai dengan potensi sosial dan budaya serta untuk melestarikan kearifan lokal.

g. Meningkatnya inovasi dan pemanfaatan tekhnologi tepat guna, informasi dan komunikasi dalam pemberdayaan masyarakat.

Pendekatan atau upaya-upaya rasional dalam mencapai tujuan program dengan memperhatikan prinsip-prinsip pengelolaan program adalah pembangunan yang berbasis masyarakat dengan menggunakan kecamatan sebagai lokus program untuk mengharmonisasikan perencanaan, pelaksanaan, dan pengendalian program.

Program pemberdayaan ekonomi melalui PNPM Mandiri Perdesaan telah dilaksanakan di desa Teluk Belitung sejak tahun 2007. Jenis Simpan Pinjam Perempuan mulai dilaksanakan tahun 2008 dan tahun 2012 ada jenis Usaha Ekonomi Produktif. Tingkat partisipasi masyarakat Desa Teluk Belitung terhadap Program nasional Pemberdayaan Masyarakat (PNPM) Mandiri perdesaan cukup baik, masyarakat memberikan tanggapan yang positif terhadap kegiatan-kegiatan yang telah terprogram, masyarakat juga ikut serta dalam tahapan-tahapan PNPM Mandiri Perdesaan, masyarakat yang merencanakan, masyarakat yang melaksanakan dan masyarakat yang menikmati hasilnya. Berikut tabel perkembangan jumlah masyarakat yang dilayani melalui PNPM Mandiri Perdesaan Desa Teluk Belitung. Berdasarkan informasi dari pengelola kegiatan PNPM, jumlah masyarakat yang dilayani mengalami peningkatan. Mereka tergabung dalam kelompok-kelompok. 
Tabel 1

Perkembangan Kelompok SPP PNPM Mandiri Kec. Merbau Kab. Kep. Meranti (Des 2013)

\begin{tabular}{|l|c|c|c|}
\hline \multicolumn{1}{|c|}{ Desa } & $\begin{array}{c}\text { Jlh } \\
\text { kel } \\
\text { awal }\end{array}$ & $\begin{array}{c}\text { Jlh kel } \\
\text { saat } \\
\text { ini }\end{array}$ & $\begin{array}{c}\text { Pertumbuhan } \\
\text { jlh kel (\%) }\end{array}$ \\
\hline $\begin{array}{l}\text { Bagan } \\
\text { Melibur }\end{array}$ & 3 & 12 & 300 \\
\hline Mengkirau & 7 & 9 & 29 \\
\hline Mengkopot & 9 & 14 & 56 \\
\hline Pelantai & 4 & 9 & 125 \\
\hline Kudap & 4 & 0 & -100 \\
\hline Dedap & 3 & 3 & 0 \\
\hline $\begin{array}{l}\text { Tanjung } \\
\text { Padang }\end{array}$ & 5 & 0 & -100 \\
\hline Selat Akar & 1 & 20 & -100 \\
\hline $\begin{array}{l}\text { Teluk } \\
\text { Belitung }\end{array}$ & 6 & 233 \\
\hline Bandul & 3 & 2 & -33 \\
\hline Lukit & 3 & 9 & 200 \\
\hline $\begin{array}{l}\text { Meranti } \\
\text { Bunting }\end{array}$ & 7 & 10 & 43 \\
\hline $\begin{array}{l}\text { Bagan } \\
\text { Melibur }\end{array}$ & 3 & 12 & 300 \\
\hline Semukut & & & 200 \\
\hline $\begin{array}{l}\text { Tanjung } \\
\text { Kulim }\end{array}$ & 4 & 6 & 50 \\
\hline Mekar Sari & 4 & 1 & -75 \\
\hline Sumber $:$ & & & \\
\hline
\end{tabular}

Sumber : Kantor PNPM Teluk Belitung

Dari tabel di atas dapat kita lihat Desa Teluk Belitung adalah desa yang paling banyak kelompoknya dari desa yang ada di kecamatan Merbau kab. Kep. Meranti yang melaksanakan PNPM Mandiri Perdesaan untuk jenis Simpan Pinjam.
Tabel2

Perkembangan Jumlah anggota yang dilayani (Des 2013)

\begin{tabular}{|c|c|c|c|}
\hline Desa & $\begin{array}{l}\text { Jeni } \\
\text { s kel }\end{array}$ & $\begin{array}{l}\text { Jlh } \\
\text { anggot } \\
\text { a yg } \\
\text { dilayan } \\
\text { i saat } \\
\text { ini }\end{array}$ & $\begin{array}{l}\text { Jlh kel dg tkt } \\
\text { perkembanga } \\
\text { n kel } \\
\text { berkembang }\end{array}$ \\
\hline $\begin{array}{l}\text { Bagan } \\
\text { Melibur }\end{array}$ & SPP & 122 & 4 \\
\hline Mengkirau & SPP & 95 & 5 \\
\hline $\begin{array}{l}\text { Mengkopo } \\
\mathrm{t}\end{array}$ & SPP & 107 & 12 \\
\hline Pelantai & SPP & 104 & 5 \\
\hline Dedap & SPP & 30 & 3 \\
\hline $\begin{array}{l}\text { Teluk } \\
\text { Belitung }\end{array}$ & SPP & 185 & 20 \\
\hline Bandul & SPP & 20 & 2 \\
\hline Lukit & SPP & 90 & 4 \\
\hline $\begin{array}{l}\text { Meranti } \\
\text { Bunting }\end{array}$ & SPP & 88 & 5 \\
\hline $\begin{array}{l}\text { Bagan } \\
\text { Melibur }\end{array}$ & SPP & 122 & 4 \\
\hline $\begin{array}{l}\text { Tanjung } \\
\text { Kulim }\end{array}$ & SPP & 62 & 2 \\
\hline Mekar Sari & SPP & 17 & 1 \\
\hline
\end{tabular}

Sumber : Kantor PNPM Teluk Belitung

Ket $: \mathrm{SPP}=$ simpan pinjam

Dari segi dana yang disalurkan mengalami peningkatan. Mulai dari jumlah pinjaman Rp. 15 juta perkelompok, tahun 2013 sudah ada yang mendapat pinjaman sebesar Rp. 100 juta/kelomok. Bagi kelompok yang sudah selesai mengembalikan pinjamannya boleh mendapatkan pinjaman selanjutnya dan plafon pinjamannya juga bisa 
ditingkatkan. Pada tahun 2013 pada seluruh tingkat/alokasi pinjaman sebesar $100 \%$ sudah dikembalikan, berarti tidak ada yang macet. Selain digunakan untuk meningkatkan pendapatan masyarakat, target program ini juga memutus mata rantai tengkulak.

Masyarakat merasakan manfaat adanya dana bergulir ini yang bisa digunakan untuk :

a. Peningkatan usaha anggota kelompok atau usaha kelompok (Usaha Ekonomi Produktif $=$ UEP).

b. Pembangunan sarana dan prasarana fasilitas umum.

c. Simpan Pinjam khusus untuk kaum perempuan untuk meningktakan ekonomi rumah tangganya (Simpan Pinjam Perempuan $=$ SPP).

Adapun berdasarkan usaha-usaha masyarakat yang mendapat pinjaman dana PNPM Mandiri Perdesaan di Desa Teluk Belitung pada tahun 2013 antara lain : usaha perdagangan barang-barang harian, sembako, pertanian (sayuran), jahitmenjahit, makanan ringan, kue basah, dan sebagainya. Masyarakat yang menggunakan mesin dan peralatan memanfaatkan dana PNPM untuk membeli peralatan yang lebih baik untuk kegiatan produksinya, seperti peralatan cetakan kue, dandang yang lebih besar pada usaha kue basah. Membeli bahan pakaian pada usaha jahit-menjahit. Ada juga yang membelikan bibit anak ayam untuk usaha ayam potong.

Beberapa ketentuan yang terdapat pada jenis Simpan Pinjam Perempuan PNPM Mandiri Perdesaan Teluk Belitung :

a. Masyarakat tergabung dalam kelompok yang berjumlah 5 sampai 10 orang.

b. KTP dari anggota kelompok.

c. Setiap kelompok yang akan mengajukan pinjaman membuat proposal sederhana yang dipandu oleh tim pengelola kegiatan PNPM Mandiri Perdesaan. d. Dalam pembayaran cicilan berlaku system bunga tetap.

e. Ada evaluasi sebelum dan sesudah dana dicairkan kepada kelompok penerima manfaat.

Berikut alokasi pinjaman dana PNPM Mandiri Perdesaan Desa Teluk Belitung dan tingkat pengembaliannya pada tahun 2013.

Tabel 3

Pinjaman SPP dan Tingkat Pengembalian Per 31 des 2013

\begin{tabular}{|c|c|c|}
\hline $\begin{array}{c}\text { Alokasi } \\
\text { Pinjaman } \\
(\mathrm{Rp} . \mathrm{Jt})\end{array}$ & Jlh kel & $\begin{array}{c}\text { Pengembalian } \\
(\%)\end{array}$ \\
\hline 15 & 4 & 100 \\
\hline 20 & & 100 \\
\hline 25 & 7 & 100 \\
\hline 30 & 6 & 100 \\
\hline 35 & 7 & 100 \\
\hline 40 & 3 & 100 \\
\hline 45 & 6 & 100 \\
\hline 50 & 16 & 100 \\
\hline 55 & 5 & 100 \\
\hline 60 & 3 & 100 \\
\hline 65 & 4 & 100 \\
\hline 70 & 4 & 100 \\
\hline 80 & 3 & 100 \\
\hline 100 & 2 & 100 \\
\hline
\end{tabular}

Sumber : Kantor PNPM Teluk Belitung

Dalam program simpan pinjam dari tabel di atas dapat dilihat tidak ada kelompok yang menunggak pengembalian pinjamannya 
(tingkat pengembaliannya 100\%). Hal ini tercapai karena ada mekanisme yang diterapkan dalam program ini untuk mengantisipasi kemacetan, yaitu jika ada anggota yang mengalami kesulitan dalam pembayaran cicilannya maka kelompok tersebut ikut bertanggung jawab terhadap pembayarannya. Mereka secara sukarela membantu anggota yang kesulitan.

Prinsip untuk saling terbuka dan menjalin komunikasi yang baik menjadi cara untuk menarik simpati dari masyarakat, selain itu kesadaran masyarakat Desa Sesulu akan kemajuan jaman membuat mereka mau untuk bergerak membangun daerah tempat tinggalnya.

\section{Evaluasi Program PNPM Mandiri Perdesaan}

Evaluasi Program Pemberdayaan Masyarakat Mandiri Perdesaan di Desa Teluk Belitung Kabupaten Kepulauan Meranti pada periode tahun 2013 terbagi menjadi dua bagian yaitu kegiatan yang sifatnya fisik seperti pembangunan sarana dan prasarana, serta kegiatan non fisik seperti pemberdayaan masyarakat melalui pelatihan keterampilan dan pendidikan. Untuk kegiatan pemberdayaan masyarakat sendiri terdapat beberapa kegiatan diantaranya: keterampilan jahit menjahit dan pelatihan pertanian. Sementara untuk kegiatan pembangunan sarana dan prasarana meliputi pembangunan Paud serta pembuatan parit dan satu jembatan ulin. Dari kegiatan di periode tersebut peneliti ingin mengevaluasi bagaimana pencapaian keberhasilan kegiatan tersebut.

$\begin{array}{ccc}\begin{array}{c}\text { Evaluasi } \\ \text { Pemberdayaan }\end{array} & \begin{array}{c}\text { Program } \\ \text { Masyarakat }\end{array} & \begin{array}{c}\text { Nasional } \\ \text { Mandiri }\end{array}\end{array}$
Perdesaan Ditinjau Dari Indikator Sukses Tingkat Partisipasi Masyarakat Masyarakat sangat mendukung kegiatan PNPM mandiri Perdesaan yang dilaksanakan didesa Teluk Belitung, karena kegiatan ini dianggap dapat menyatu dengan masyarakat, masyarakat yang merencanakan, masyarakat yang melaksanakan, dan masyarakat yang menikmatinya, misalnya gedung-gedung yang telah dibangun dapat digunakan masyarakat sesuai dengan keperluannya, selain itu kegiatan PNPM mandiri perdesaan yang dilakukan didesa Teluk Belitung ini mengutamakan dibidang pendidikan dan kesehatan seperti memberikan pelatihan keterampilan- keterampilan masyarakat dan pembangunan sarana kesehatan seperti posyandu. Secara keseluruhan masyarakat desa Teluk Belitung mendukung dan proaktif dalam kegiatan karena mereka selalu dilibatkan dalam perencanaan kegiatan, pelaksanaan kegiatan, dan penyampaian hasil kegiatan yang nantinya dapat dirasakan sendiri hasilnya oleh masyarakat desa Teluk Belitung.

Tingkat Perkembangan

Kelembagaan Dalam pelaksanaan PNPM perdesaan di setiap desa terdapat kader pemberdayaan masyarakat desa (KPMD), seperti halnya di Desa Teluk Belitung juga memiliki kader pemberdayaan masyarakat desa. Kader pemberdayaan masyarakat desa yang telah terpilih dalam musyawarah desa sosialisasi, akan memandu serangkaian tahapan kegiatan PNPM mandiri perdesaan yang diawali dengan proses penggalian gagasan ditingkat dusun dan kelompok masyarakat. Sebelum melakukan tugasnya mereka akan diberikan pelatihan-pelatihan agar memiliki pemahaman dalam menjalakan tugasnya. Dalam pelaksanaan PNPM Mandiri Perdesaan terdapat kader pemberdayaan masyarakat, mereka adalah warga terpilih yang memfasilitasi dan memandu masyarakat dalam pelaksanaan PNPM mandiri perdesaan di Desa Teluk Belitung. Untuk memberikan bekal bagi kader-kader pemberdayaan masyarakat dilakukan pelatihan hal ini juga mempermudah dalam mendampingi masyarakat dan fasilitator kecamatan dalam 
tahapan kegiatan, Secara keseluruhan dalam peningkatan kelembagaan dilakukan sesuai dengan prosedur yang terdapat dalam pedoman teknik operasional, baik itu pelatihan-pelatihan bagi kader pemberdayaan masyarakat desa dan pemilihan tim pengelola kegiatan.

Secara keseluruhan dalam membangun sarana dan prasarana Tim Pengelola Kegiatan selalu melibatkan masyarakat, Tim pengelola kegiatan juga selalu kooperatif dengan masyarakat baik dalam menerima usulan warga maupun dalam hal transparansi keuangan.

$$
\text { Evaluasi Program Nasional }
$$

Pemberdayaan Masyarakat Mandiri Perdesaan Ditinjau Dari Indikator Kerja Peningkatan partisipasi masyarakat Partisipasi masyarakat sangatlah penting demi keberhasilan suatu kegiatan dalam PNPM Mandiri Perdesaan. Masyarakat diharapkan berpartisipasi atau terjun dalam program baik secara langsung maupun tidak, mengapa demikian karena masyarakat dalam kebijakan ini yang diberdayakan. Oleh karena itu maka Tim Pengelola kegiatan melakukan usaha-usaha dalam menarik simpati masyarakat Desa Sesulu agar mau berpartisipasi kegiatan. Secara keseluruhan yang dapat saya simpulkan sebagai penulis dari beberapa pendapat responden dalam hal upaya peningkatan partisipasi masyarakat adalah dengan menunjukkan kinerja mereka baik sebagai pembina maupun tim pengelola kegiatan pada masyarakat, dengan menunjukan kinerja yang baik maka secara langsung dapat meningkatkan rasa kepercayaan masyarakat terhadap mereka dan diharapkan dapat pula mendorong mereka untuk ikut berpartisipasi.

Hal yang harus diperhatikan dalam perencanaan partisipatif PNPM Mandiri adalah keterlibatan perangkat pemerintahan desa/kelurahan (pemerintah desa/kelurahan, Badan Permusyawaratan Desa/BPD, dan lembaga kemasyarakatan desa/kelurahan) dalam memfasilitasi masyarakat. Oleh sebab itu perlu dilakukan peningkatan kapasitas perangkat pemerintahan desa/kelurahan dalam menjaring aspirasi, permasalahan, dan potensi masyarakat secara nyata.

Tolok ukur sektor secara umum adalah sebagai berikut:

1. Keterlibatan penduduk miskin, perempuan, dan kelompok marjinal dalam proyek padat karya semakin besar.

2. Penurunan jumlah penganggur dalam kurun waktu satu tahun pelaksanaan program.

3. Peningkatan pendapatan masyarakat miskin dalam kurun waktu satu tahun.

4. Adanya peraturan keuangan mikro yang pro poor dan mudah diterapkan.

5. Peningkatan lembaga kredit mikro yang dapat dimanfaatkan oleh masyarakat miskin dan peningkatan antusiasme masyarakat miskin untuk mengaksesnya.

6. Menurunnya kemauan masyarakat miskin untuk mengakses dana pinjaman rentenir.

7. Peningkatan jumlah usaha baru dari masyarakat miskin yang dapat dikembangkan melalui program.

8. Peningkatan produktifitas usaha baru dari masyarakat miskin yang dapat dikembangkan melalui program.

9. Peningkatan tenaga kerja yang dilibatkan dalam usaha baru dari masyarakat miskin yang dapat dikembangkan melalui program.

10. Peningkatan kemampuan masyarakat miskin dalam pengelolaan ekonomi produktif.

11. Meningkatnya keterhubungan faktor produksi dan pasar.

12. Peningkatan kemampuan masyarakat miskin dalam mengkonsumsi barang, terutama kebutuhan pangan.

13. Peningkatan kualitas ibu hamil, menyusui, dan anak. 
14. Penurunan kematian ibu hamil, bayi, dan balita.

15. Peningkatan supply air bersih dan penggunaan air bersih oleh masyarakat.

16. Peningkatan partisipasi anak dalam pendidikan dasar dan menengah.

17. Peningkatan sanitasi lingkungan permukiman kelompok masya- rakat miskin.

Tolok ukur kepuasan penerima manfaat secara umum adalah sebagai berikut:

1. Tingkat kepuasan masyarakat miskin terhadap pelayanan pemerin- tah daerah dengan adanya PNPM Mandiri, terutama untuk pelayanan dasar.

2. Tingkat kepuasan masyarakat dalam keterlibatannya pada proses penetapan proyek dalam PNPM Mandiri.

3. Tingkat kepuasan warga dengan kinerja pokmas yang menyalurkan dana untuk mereka.

4. Tingkat kepuasan pokmas dan warga dengan prosedur penyaluran dana yang diberlakukan PNPM Mandiri.

5. Tingkat kepuasan warga terhadap hasil dari proyek-proyek pembangunan yang dijalankan bersama (pemerintah dan masya- rakat) dari PNPM Mandiri.

6. Penilaian warga terhadap perbaikan tingkat kesejahteraannya (kesehatan, ekonomi dan konsumsi rumah tangga, dll) dengan adanya PNPM Mandiri

7. Tingkat kepuasan warga terhadap pola kredit yang diberlakukan oleh unit pelaksana kredit atas bantuan PNPM Mandiri.

\section{SIMPULAN}

Tingkat partisipasi masyarakat Desa Teluk Belitung terhadap Program nasional Pemberdayaan Masyarakat (PNPM) Mandiri perdesaan cukup baik, masyarakat memberikan tanggapan yang positif terhadap kegiatan-kegiatan yang telah terprogram, masyarakat juga ikut serta dalam tahapan-tahapan PNPM Mandiri Perdesaan, masyarakat yang merencanakan, masyarakat yang melaksanakan dan masyarakat yang menikmati hasilnya

Prinsip untuk saling terbuka dan menjalin komunikasi yang baik menjadi cara untuk menarik simpati dari masyarakat, selain itu kesadaran masyarakat Desa Teluk Belitung akan kemajuan jaman membuat mereka mau untuk bergerak membangun daerah tempat tinggalnya. Tingkat perkembangan kelembagaan di Desa Teluk Belitung dengan adanya Program Nasional Pemberdayaan Masyarakat (PNPM) Mandiri Perdesaan sebagian besar hanya mencangkup beberapa kelompok atau organisasi dalam PNPM Mandiri perdesaan tersebut. Dengan memberikan pelatihanpelatihan pada kader pemberdayaan masyarakat yang telah ditunjuk untuk mendampingi masyarakat dalam tahapantahapan PNPM Mandiri Perdesaan di Desa Teluk Belitung.

\section{DAFTAR PUSTAKA}

eJournal Ilmu Pemerintahan, Volume 1, Nomor 2, 2013: 1-13

Moleong, Lexy J. 2007. Metodologi Penelitian Kualitatif. Bandung: PT. Remaja Rosdakarya.

Usman Sunyato . 2004. Pembangunan dan Pemberdayaan Masyarakat.

Yogyakarta: Pustaka Pelajar.

eJournal Ilmu Pemerintahan, Volume 1, Nomor 2, 2013: 1-13

http://www.Pnpm-mandiri/perdesaan.org

http://www.Pnpm-mandiri.org

http://www.Bapedda.go.id

http://teoripemberdayaan.blogspot.com 